\title{
Bovine ovarian non-genomic progesterone binding sites: presence in follicular and luteal cell membranes
}

\author{
M T Rae ${ }^{1}$, G S Menzies ${ }^{2}$ and T A Bramley ${ }^{2}$ \\ ${ }^{1}$ Department of Biosciences, University of Kent at Canterbury, Canterbury, Kent CT2 7NJ, UK and ${ }^{2}$ The University of Edinburgh Department of Obstetrics and \\ Gynaecology, Centre for Reproductive Biology, 37 Chalmers Street, Edinburgh EH3 9EW, UK \\ (Requests for offprints should be addressed to T A Bramley)
}

\begin{abstract}
We have shown recently that the bovine corpus luteum (CL) possesses specific luteal cell surface membrane binding sites for progesterone. We have now confirmed and extended these observations to compare the subcellular distribution of these binding sites in developing, mature and regressing CL. The median buoyant densities of luteal progesterone binding sites from early-, mid- and late-luteal phase CL were similar (though three of five density profiles for late-luteal phase CL showed association of steroid binding with a fraction with a lower density), and clearly resolved from nuclear, mitochondrial, lysosomal, peroxisomal, Golgi-endoplasmic reticulum-lysosomal and smooth endoplasmic reticulum markers. Specific binding of $\left[{ }^{3} \mathrm{H}\right]$ progesterone overlapped with the distributions of 5 -nucleotidase and luteinizing hormone receptor (luteal cell surface membrane markers) in both control and digitonin-treated gradients at all stages of the luteal phase.

Since steroidogenic 'large luteal' and 'small luteal' cells of the CL are derived from the granulosa cells (GC) and theca of the preovulatory follicle, we also investigated whether similar receptors were present in the follicle, and describe for the first time specific membrane binding sites for progesterone in purified GC and thecal membranes
\end{abstract}

from healthy bovine follicles of different sizes. Specific binding increased linearly with GC and thecal membrane protein concentration; however, it was detectable only when digitonin was included in the binding incubation. Binding sites were specific for progesterone; unlabelled progesterone competed for $\left[{ }^{3} \mathrm{H}\right]$ progesterone binding at low concentrations $\left(\mathrm{IC}_{50}, 35\right.$ and $\left.31 \mathrm{nmol} / \mathrm{l}\right) \mathrm{com}-$ pared with testosterone $\left(\mathrm{IC}_{50}, 905\right.$ and $\left.870 \mathrm{nmol} / \mathrm{l}\right)$ and $\Delta^{4}$-androstenedione $\left(\mathrm{IC}_{50}, 1050\right.$ and $\left.660 \mathrm{nmol} / \mathrm{l}\right)$ for $\mathrm{GC}$ and thecal receptors respectively. In contrast, oestradiol, oestrone, pregnenolone, cortisol, cholesterol, and a genomic progesterone receptor antagonist, RU486, competed poorly.

Steroid binding was present in GC and thecal membranes of follicles of all sizes, but $\left[{ }^{3} \mathrm{H}\right]$ progesterone binding to GC membranes decreased significantly with increasing follicle size $(P<0 \cdot 02)$, perhaps indicating developmental regulation of GC membrane non-genomic progesterone receptors in the preovulatory bovine follicle. We suggest that these membrane steroid receptors may be involved in the autocrine/paracrine regulation of follicular function by progesterone.

Journal of Endocrinology (1998) 159, 413-427

\section{Introduction}

Ovarian tissues of several species have been shown to possess genomic progesterone receptors (Rossmanith et al. 1991, Duffy et al. 1996, Park-Sarge et al. 1996, Pinter et al. 1996) which regulate a number of different ovarian cell functions by activation or suppression of gene transcription (Jones et al. 1992, Asem \& Conkright 1995, Metherall et al. 1996). However, some physiological effects of progesterone are not blocked by inhibitors of transcription or translation, are unaffected by covalent coupling of steroid to cell-impermeant protein, are not antagonized by classical antagonists of genomic steroid receptors, and are too rapid to be due to changes in gene expression (Wehling 1997). Whilst some of these rapid steroid effects are clearly mediated in some tissues by modulation of other receptors by progesterone or its metabolites (Baulieu \& Robel 1995, Picard 1998), evidence has accumulated recently for the existence of non-genomic cell surface membrane steroid receptors for vitamin D, thyroid hormones, corticoids and the major sex steroids (Brann et al. 1996, Ramirez \& Zheng 1996, Rupprecht et al. 1996, Wehling 1997, Revelli et al. 1998). In particular, membrane receptors for progesterone have been described in several tissues, including brain (Caldwell et al. 1995, Mahesh et al. 1996, Ramirez \& Zheng 1996, Zheng et al. 1996, Joels 1997, Wiebe 1997), intestinal smooth muscle (Bielefeldt et al. 1996), adrenal chromaffin cells (Dar \& Zinder 1997), liver (Meyer et al. 1996, 1998), amphibian oocytes (Sadler \& Maller 1982, Liu \& Patino 1993, Bandyopadhyay et al. 1998) and human sperm (Blackmore et al. 1990, 1994, 1996, Alexander et al. 1996, Ambhaikar 
\& Puri 1998, Luconi et al. 1998), where its presence may indicate fertilizing outcome (Jacob et al. 1998). Work on the human sperm membrane progesterone receptor has shown progesterone mediates a number of physiologically important events (Tesarik et al. 1993, Aitken et al. 1998), including stimulation of the acrosome reaction (Sabeur et al. 1996) and hyperactivated sperm movement (Parinaud \& Milhet 1996). However, attempts to isolate non-genomic membrane receptors from different tissues using different detection techniques have so far identified a diverse range of progesterone-binding proteins of different sizes, affinities and binding specificities (Eisen et al. 1997.

Recently, rapid, non-genomic effects of progesterone on porcine granulosa cell (GC) function were demonstrated (Machelon et al. 1996). However, binding of steroid to the putative receptors was not demonstrated. We have shown recently that highly purified bovine luteal membranes possess high levels of specific binding sites for progesterone (Rae et al. 1998). As the secretory activity of the corpus luteum (CL) changes markedly throughout its lifespan, we may expect the levels and/or subcellular distributions of these binding sites to alter as progesterone secretion rises and declines. We therefore measured the distribution of $\left[{ }^{3} \mathrm{H}\right]$ progesterone binding sites in developing, mature and regressing bovine CL. To distinguish activities associated with the cell surface membrane from those associated with intracellular organelles, we utilized the saponin, digitonin, which forms a 1:1 complex with cholesterol (Severs \& Robenek 1983). Pretreatment with digitonin increases the buoyant density of membranes with a high unesterified cholesterol content (plasma membranes, endosomes, Golgi), but intracellular membranes (which have much lower unesterified cholesterol contents) are not perturbed appreciably (see Bramley \& Menzies 1988 a for discussion).

The CL forms from the remnants of the preovulatory follicle. GC can be recovered from the avascular follicular fluid without significant contamination by blood vessel elements, and without requiring enzymatic cell dispersion. Moreover, in contrast to the large amounts of progesterone secreted by the CL, the follicle secretes little progesterone until just before ovulation, reducing the possibility of occupancy of binding sites by endogenous progesterone. We therefore investigated whether progesterone binding sites were present in purified GC and thecal membranes from healthy follicles of different sizes. We report for the first time the presence of GC and thecal membrane-bound progesterone receptors, their initial characterization and their levels in follicular cell membranes from follicles at different stages of development.

\section{Materials and Methods}

Digitonin was purchased from Aldrich (Gillingham, Dorset, UK) or from BDH (Poole, Dorset, UK) and was of the purest grade obtainable. All other fine chemicals, reagents and unlabelled steroids were purchased from Sigma Chemical Co. (Poole, Dorset, UK), from BDH or from Amersham International plc (Amersham, Bucks, UK) and were of analytical grade. The progesterone receptor antagonist (RU 38486) was a gift of Dr K J Thong, Department of Obstetrics and Gynaecology, The University of Edinburgh. $\left[1,2,6,7-{ }^{3} \mathrm{H}\right]$ Progesterone $(100 \mathrm{Ci} / \mathrm{mmol})$ was purchased from New England Nuclear Research Products, Du Pont (UK) Ltd (Stevenage, Herts, UK) and $\left[{ }^{125} \mathrm{I}\right] \mathrm{NaI}$ was purchased from Amersham International plc. Highly purified human chorionic gonadotrophin (hCG; Profasi; $5000 \mathrm{IU} /$ vial) was purchased from Serono Ltd, (Welwyn Garden City, Herts, UK) and was radioiodinated to a specific binding activity of $20 \mathrm{Ci} / \mathrm{g}$ as described previously (Bramley \& Menzies 1988b).

\section{Ovarian tissue}

Ovaries from non-pregnant cows slaughtered at a local abattoir were transported to the laboratory in warm phosphate-buffered saline (PBS; sodium chloride $(0.15 \mathrm{~mol} / \mathrm{l})$ in sodium phosphate $(10 \mathrm{mmol} / \mathrm{l}), \mathrm{pH} 7 \cdot 4)$ within $1 \mathrm{~h}$ of death. The stage of the luteal phase of the oestrous cycle was assessed from the morphology of the ovaries, as described by Fields \& Fields (1996). GC were aspirated from clear, blood-free, non-atretic follicles of different size classes $(<5 \mathrm{~mm}$ diameter, small; $5-10 \mathrm{~mm}$ diameter, medium; $>10 \mathrm{~mm}$ diameter, large follicles), pooled, centrifuged in a clear plastic conical centrifuge tube (1000 $g$ for $5 \mathrm{~min}$ ) and washed twice in Dulbecco's phosphate-buffered saline (Flow Laboratories, Irvine, Scotland). The volume of the cell pellet was measured, and cells were homogenized in ice-cold SET medium ( $0.3 \mathrm{~mol} / 1$ sucrose, $1 \mathrm{mmol} / 1 \mathrm{EDTA}, 10 \mathrm{mmol} / 1 \mathrm{Tris}-$ $\mathrm{HCl}, \mathrm{pH} 7 \cdot 4$ ) at $10 \mathrm{ml} / \mathrm{ml}$ packed cells with 20 complete strokes of an all-glass Dounce homogenizer.

Thecal tissue was recovered from hemissected follicles by gently scraping off adhering GC with a plastic spatula and peeling away the thecal layer with blunt forceps. Pooled thecal tissue from small, medium or large follicles was rinsed, minced with scissors and homogenized in ice-cold SET medium $(10 \mathrm{ml} / \mathrm{g}$ wet weight $)$ using a Polytron homogenizer (Kinematica, Lucerne, Switzerland) with two $10 \mathrm{~s}$ bursts at full speed, interspersed with a $1 \mathrm{~min}$ cooling period on ice. Homogenates were then filtered through two layers of cheesecloth.

CL homogenates were prepared from early-, mid- and late-luteal CL (staged according to Fields \& Fields 1996). Homogenates were preincubated $\left(30 \mathrm{~min}\right.$ at $\left.0{ }^{\circ} \mathrm{C}\right)$ with $0.5 \mathrm{ml} \mathrm{SET}$ alone, or SET containing $10 \mathrm{mg} / \mathrm{ml}$ digitonin, and fractionated as described previously (Rae et al. 1998).

\section{Sucrose density gradient fractionation}

Continuous sucrose density gradients $(30 \mathrm{ml} ; 10-50 \%$ w/w) were prepared by the method of Stone (1974). 
Aliquots of homogenate $(1-3 \mathrm{ml})$ were gently layered over the sucrose density gradients and centrifuged at $30000 \boldsymbol{g}_{\text {av }}$ for $2 \mathrm{~h}$ in a Sorvall VTR 50 vertical tube rotor $\left(4{ }^{\circ} \mathrm{C}\right)$. Each gradient was then fractionated from above using a Buchler-Searle (Fort Lee, NJ, USA) Autodensiflo gradient fractionator equipped with a meniscus-sensitive probe, and gradient fractions $(1 \mathrm{ml})$ frozen at $-20{ }^{\circ} \mathrm{C}$ until assay.

\section{Assays}

Sucrose content of density gradient fractions was measured using an Abbe refractometer (Atago, Japan). Protein was measured by the method of Lowry et al. (1951) using BSA as a standard. Optimal conditions for the measurement of a panel of marker activities specific for the major subcellular organelles and luteal plasma membranes of the bovine CL, for specific binding of $\left[{ }^{3} \mathrm{H}\right]$ progesterone and ${ }^{125} \mathrm{I}-\mathrm{hCG}$, and for the measurement of endogenous progesterone content by RIA have been described in detail previously (Rae et al. 1998). Fractions enriched in progesterone binding activity were pooled and stored at $-20{ }^{\circ} \mathrm{C}$ for further analysis. Freezing and thawing of fractions substantially decreased NADH-cytochrome C reductase activity, and this marker was therefore measured before other markers. However, freeze-thawing did not affect other markers or decrease progesterone binding activity (data not shown).

In a single experiment, addition of a panel of protease inhibitors (pepstatin A, phenylmethylsulphonylfluoride, N-ethyl maleimide, EDTA) to the homogenization medium did not alter the buoyant density distributions or the activities of cell membrane and organelle markers following fractionation of a mid-luteal CL (data not shown).

\section{Steroid binding to bovine ovarian membrane fractions in vitro}

Aliquots $(5-50 \mu \mathrm{l})$ of bovine ovarian membrane fractions were incubated at $4{ }^{\circ} \mathrm{C}$ for $2 \mathrm{~h}$ in a $0.5 \mathrm{ml}$ binding system containing $40 \mathrm{mmol} / 1$ Tris- $\mathrm{HCl}(\mathrm{pH} 7 \cdot 4), 0 \cdot 1 \%(\mathrm{w} / \mathrm{v})$ BSA, 50000 c.p.m. $\left[{ }^{3} \mathrm{H}\right]$ progesterone and digitonin $(250 \mu \mathrm{mol} / \mathrm{l})$. Bound and unbound tracer were separated by addition of $1.0 \mathrm{ml}$ ice-cold vigorously-stirred dextrancoated charcoal (2.5 g activated charcoal (250-350 mesh; Sigma) and $0.25 \mathrm{~g}$ Dextran- $\mathrm{T}$ in $500 \mathrm{ml}$ assay buffer). Tubes were centrifuged at $3750 \mathrm{~g}_{\text {av }}$ for $10 \mathrm{~min}\left(4^{\circ} \mathrm{C}\right)$, supernatants were decanted into scintillation vials and mixed with $4 \mathrm{ml}$ scintillant (Ecoscint A, National Diagnostics, Atlanta, GA, USA), and then their tritium counted in an LKB Rackbeta II scintillation counter. Tubes containing digitonin but no membranes, and tubes with membranes but no digitonin were routinely included as negative controls. A membrane fraction prepared by gradient fractionation of pooled mid-luteal sheep CL was routinely included as a positive control.
For binding specificity experiments, steroids were dissolved in ethanol, added to the assay tubes, then dried down at room temperature under a stream of nitrogen. Assay buffer was then added, the tubes vortexed vigorously $(30 \mathrm{~s})$, then assay cocktail added and incubation begun. Binding of $\left[{ }^{3} \mathrm{H}\right]$ progesterone was measured in the absence and in the presence of increasing concentrations of each test substance, and binding plotted against $\log _{10}$ concentration. Concentrations of steroids required to inhibit progesterone binding by $50 \%\left(\mathrm{IC}_{50}\right)$ were calculated graphically.

\section{Analysis of data}

The significance of differences in steroid binding to GC and thecal membranes from follicles of different sizes was assessed by Student's $t$-test. A $P$ value of $<0.05$ was regarded as significant.

Buoyant density profiles for each marker activity were constructed from plots of activity versus sucrose concentration for each sucrose density gradient fraction. Plots were triangulated, and the sucrose concentration equivalent to $67 \%$ of the triangulated peak height on both sides of the activity peak (representing \pm 1 standard deviation from the modal buoyant density) was calculated graphically. Sucrose concentrations were converted to density using standard tables. Frequency plots of buoyant density range were then constructed for each marker (see Bramley $\&$ Menzies $1988 a$ for details).

\section{Results}

$C L$

Buoyant density profiles for $\left[{ }^{3} \mathrm{H}\right]$ progesterone binding activity in vitro, and for a number of luteal cell surface and intracellular organelle marker enzymes have been published previously for mid-luteal phase bovine CL (Rae et al. 1998). Figure 1 shows a composite of buoyant density data from fractionation of a number of mid-luteal phase CL with (lower panels) or without (upper panels) pretreatment with digitonin.

$\left[{ }^{3} \mathrm{H}\right]$ Progesterone binding in vitro equilibrated at a median buoyant density of $1 \cdot 100-1 \cdot 115 \mathrm{~g} / \mathrm{cm}^{3}$ (Fig. 1A, upper plot) and was perturbed by preincubation of luteal homogenates with digitonin (to $1 \cdot 125-1 \cdot 150 \mathrm{~g} / \mathrm{cm}^{3}$; Fig. 1A, lower plot). In contrast, cytochrome oxidase (a mitochondrial marker) equilibrated at $1 \cdot 15-1 \cdot 16 \mathrm{~g} / \mathrm{cm}^{3}$ (Fig. 1B, upper plot), and was not perturbed significantly by digitonin pretreatment (Fig. 1B, lower plot). The buoyant density profiles of other intracellular organelle markers (fluoride-sensitive acid phosphatase (Golgiendoplasmic reticulum-lysosomal membranes), Fig. 1C; $\mathrm{NADH}$-cytochrome $\mathrm{C}$ reductase (and NADPHcytochrome C reductase, data not shown) (smooth endoplasmic reticulum (SER) membranes), Fig. 1D; 


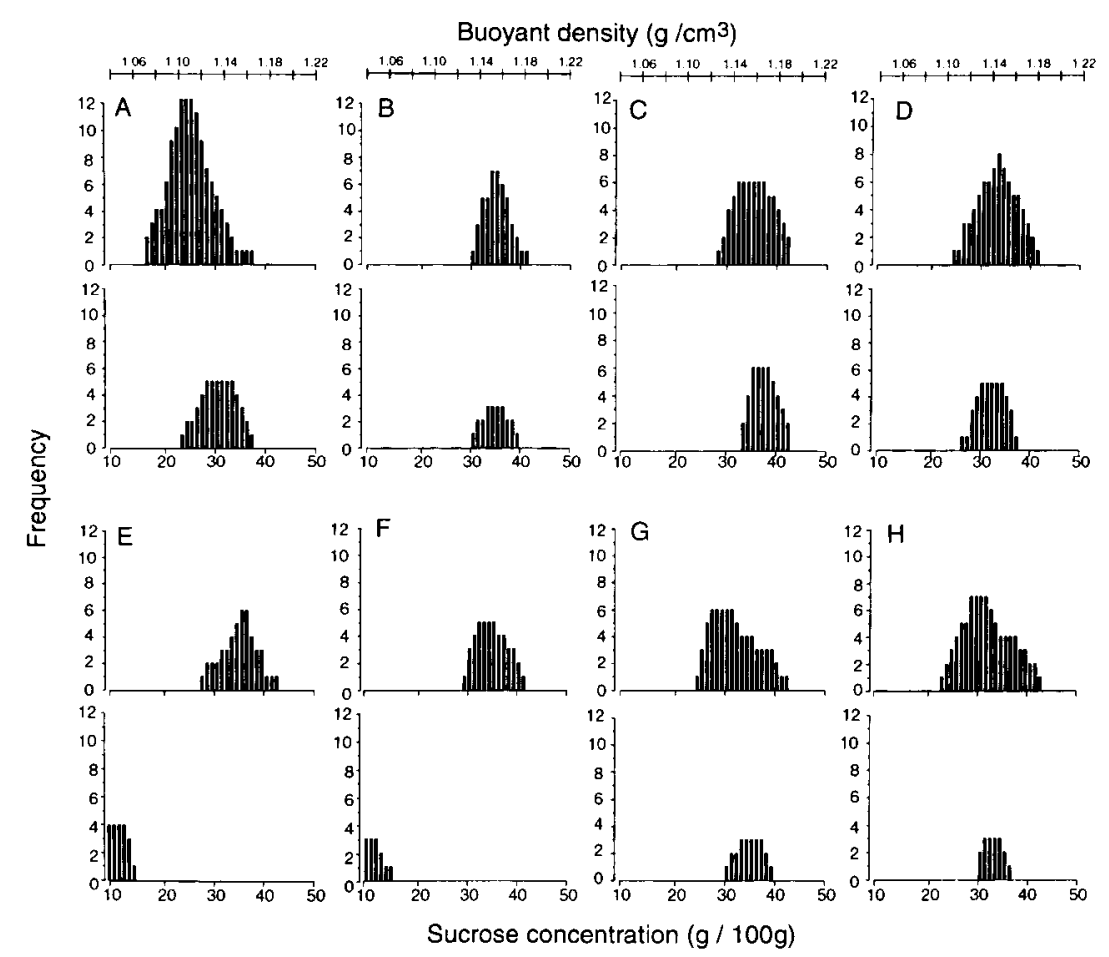

Figure 1 Buoyant density profiles of $\left[{ }^{3} \mathrm{H}\right]$ progesterone binding, and intracellular and cell surface membrane marker enzymes of bovine mid-luteal $\mathrm{CL}$, without (upper panels) or with (lower panels) preincubation with digitonin. Homogenates of bovine mid-luteal tissue were prepared as described in Materials and Methods and aliquots $(2-3 \mathrm{ml})$ preincubated (30 min, $0{ }^{\circ} \mathrm{C}$ ) with $0.5 \mathrm{ml} \mathrm{SET} \mathrm{medium} \mathrm{alone} \mathrm{(controls,} \mathrm{upper} \mathrm{plots)} \mathrm{or} \mathrm{with} 0.5 \mathrm{ml} \mathrm{SET}$ containing digitonin $(10 \mathrm{mg} / \mathrm{ml}$, lower plots). Aliquots $(2 \cdot 5-3 \mathrm{ml})$ were then centrifuged on continuous sucrose density gradients, and gradient fractions collected. Triplicate aliquots of each gradient fraction were tested for specific binding of $\left[{ }^{3} \mathrm{H}\right]$ progesterone in the presence and absence of digitonin, and for marker enzyme content, and activity plotted against sucrose concentration. Buoyant density was calculated from triangulated activity plots of activity versus density, as described previously (Bramley \& Menzies 1988a), and histograms of frequency versus buoyant density were constructed. (A) $\left[{ }^{3} \mathrm{H}\right]$ Progesterone binding in vitro; (B) cytochrome oxidase; (C) fluoride-sensitive acid phosphatase; (D) NADHcytochrome $\mathrm{C}$ reductase; (E) N-acetyl- $\beta$-glucosaminidase; (F) catalase; (G) 5 '-nucleotidase; (H) specific binding of ${ }^{125} \mathrm{I}$-hCG.

$N$-acetyl- $\beta$-glucosaminidase (lysosomes), Fig. 1E; catalase (peroxisomes), Fig. 1F; and DNA content (nuclei $>1.20 \mathrm{~g} / \mathrm{cm}^{3}$; data not shown)) also differed from that of progesterone binding activity, with or without digitonin pretreatment. (Treatment of luteal homogenates with digitonin disrupted peroxisomal and lysosomal membranes, releasing their contents and resulting in the quantitative recovery of catalase and $\mathrm{N}$-acetyl- $\beta$ glucosaminidase activities in fractions at the top of the gradient: Fig. 1E and F, cf. upper and lower plots.)

The buoyant density profile of $\left[{ }^{3} \mathrm{H}\right]$ progesterone binding in vitro (Fig. 1A, upper plot) most closely resembled profiles for the luteal plasma membrane markers, 5'nucleotidase (Fig. 1G, upper plot) and specific binding of ${ }^{125} \mathrm{I}$-hCG (Fig. 1H, upper plot); all were perturbed similarly by digitonin (Fig. 1A, G and $\mathrm{H}$, lower plots).

\section{Early-luteal CL}

Buoyant density profiles for $\left[{ }^{3} \mathrm{H}\right]$ progesterone binding to early-luteal CL $\left(1 \cdot 100-1 \cdot 145 \mathrm{~g} / \mathrm{cm}^{3}\right.$; Fig. $\left.2 \mathrm{~A}-\mathrm{C}\right)$ were similar to those of mid-luteal CL $\left(1 \cdot 100-1 \cdot 115 \mathrm{~g} / \mathrm{cm}^{3} \mathrm{cf}\right.$. Fig. 2B and $\mathrm{C}$ and Fig. 1A upper and lower plots). Digitonin pretreatment increased the buoyant density of $\left[{ }^{3} \mathrm{H}\right]$ progesterone binding significantly (Fig. 2A), though it decreased total recovery relative to controls (Fig. 2A) due to partial loss of binding with the high digitonin concentrations used for density perturbation experiments (data not shown). Interestingly, significant $\left[{ }^{3} \mathrm{H}\right]$ progesterone binding was not measured in fractions from either control or digitonin-pretreated gradients unless digitonin was included in the binding assay (Fig. 2A, open symbols - see below). 


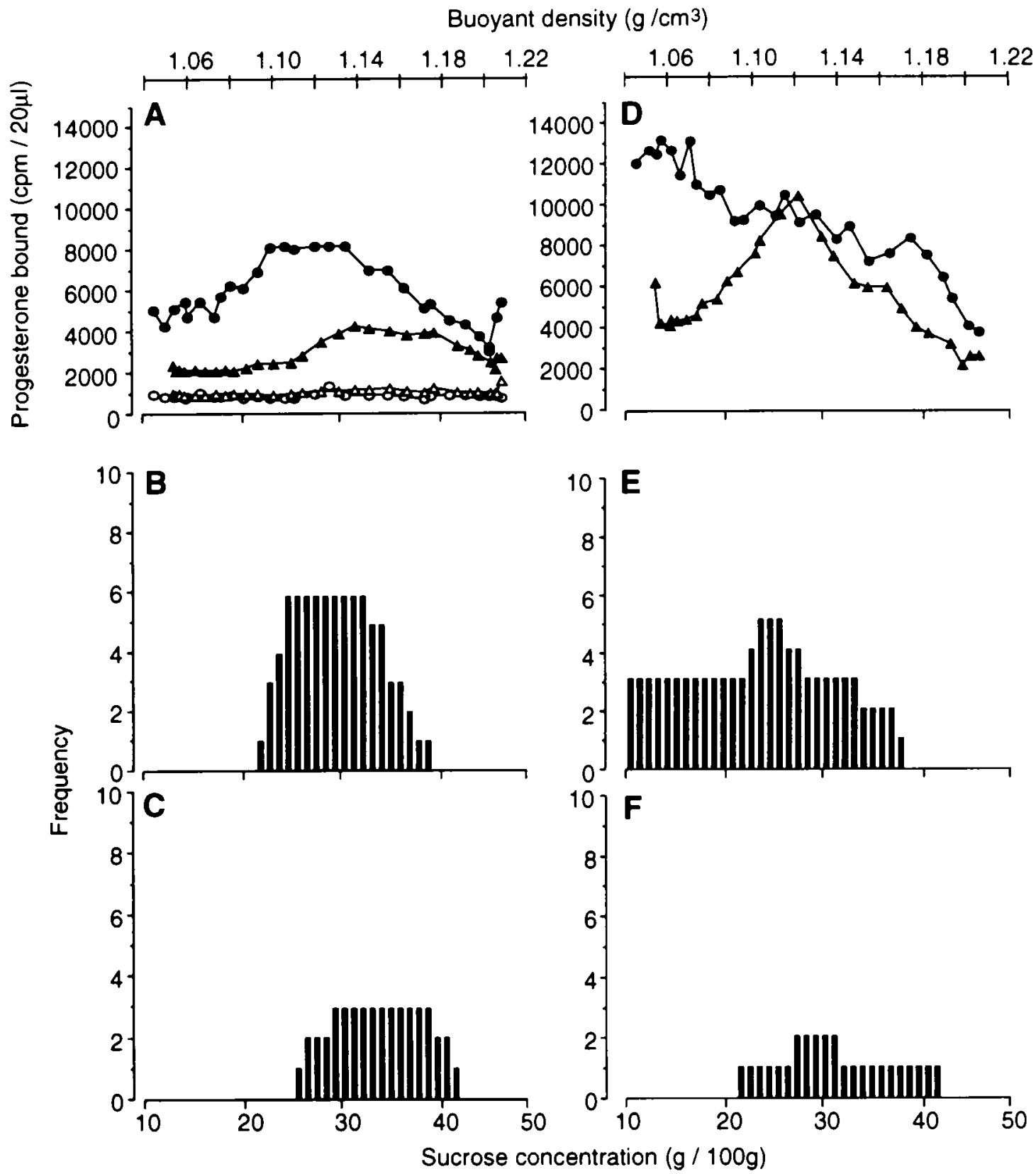

Figure 2 Buoyant density profiles of $\left[{ }^{3} \mathrm{H}\right]$ progesterone binding to early- (A-C) and late- (D-F) luteal CL fractions. Bovine $\mathrm{CL}$ from the early- (A) or late- (D) luteal phase were homogenized, preincubated with SET alone (circles) or with SET

containing $10 \mathrm{mg} / \mathrm{ml}$ digitonin (triangles) and fractionated on sucrose density gradients, as described in the legend to Fig. 1. $\left[{ }^{3} \mathrm{H}\right]$ Progesterone binding was measured in vitro (triplicate) in aliquots of each gradient fraction in the absence (open symbols) or presence of $250 \mu \mathrm{mol} / \mathrm{l}$ digitonin (solid symbols) in the binding assay. Frequency plots of buoyant density of $\left[{ }^{3} \mathrm{H}\right]$ progesterone binding to fractions from early- $(\mathrm{B}$ and $\mathrm{C})$ or late- $(\mathrm{E}$ and $\mathrm{F})$ luteal $\mathrm{CL}$ homogenates pretreated with $(\mathrm{C}$ and F) or without (B and E) digitonin.

Specific binding of ${ }^{125} \mathrm{I}-\mathrm{hCG}$ to early-luteal membrane fractions equilibrated at a somewhat heavier density $(1 \cdot 15-$ $\left.1 \cdot 19 \mathrm{~g} / \mathrm{cm}^{3}\right)$ than that for mid-luteal membranes, and was perturbed less by digitonin pretreatment (data not shown).
Buoyant densities of all intracellular organelle markers measured fell within the ranges described above for mid-luteal phase CL, with and without digitonin pretreatment (data not shown). 


\section{Late-luteal CL}

Unlike the profiles observed following fractionation of mid- and early-luteal CL, three of five late-luteal CL fractionated showed significant progesterone binding activity associated with a low-density fraction recovered in the upper, low-density regions of the gradient (Fig. 2D and $\mathrm{E})$. However, these membranes were still perturbed by digitonin pretreatment (cf. Fig. 2E and F). There were also minor changes in mitochondrial density (reduced to $\left.1 \cdot 12-1 \cdot 14 \mathrm{~g} / \mathrm{cm}^{3}\right)$ in late-luteal CL, and a greater proportion of lysosomal and peroxisomal markers was recovered in fractions at the top of the gradient, suggesting that these organelles were more fragile and more readily disrupted by homogenization in regressing CL. The buoyant densities of all other organelle markers fell within the ranges described above for mid-luteal phase CL, both with and without digitonin pretreatment, however (data not shown).

Protein and progesterone content of early-, mid-and late-luteal phase CL

Profiles of protein content were similar for early-, midand late-luteal gradients (Fig. 3A-C), with high levels in cytosolic fractions at the top of the gradients, and broad peaks of protein associated with the major band of intracellular organelles. The distribution of protein content was largely unaltered by digitonin pretreatment.

Progesterone content was greatest in cytosol fractions at the top of the gradients (Fig. 3D-F), and in nuclear pellets (Fig. 3). However, a broad band of progesterone was also associated with particulate fractions (see for instance Fig. 3F). Moreover, pretreatment of homogenates with digitonin prior to fractionation significantly decreased the progesterone content of cytosol fractions (simultaneously increasing the association of progesterone with particulate fractions), and shifted progesterone content peak to a heavier buoyant density (at least for early- and mid-luteal CL, Fig. 3E and F). Note that the peaks of progesterone content did not coincide with those fractions having the greatest protein content.

Progesterone binding to membranes of cells of the preovulatory follicle

The much smaller amounts of tissue recovered from the preovulatory follicle precluded studies of the effects of digitonin perturbation; hence, homogenates of thecal and GC were fractionated on sucrose gradients without digitonin pretreatment.

GC

Sucrose gradient fractionation of homogenates of bovine GC from small follicles demonstrated a clear peak of $\left[{ }^{3} \mathrm{H}\right]$ progesterone binding (median buoyant density, 1·13$1.15 \mathrm{~g} / \mathrm{cm}^{3}$; Fig. $4 \mathrm{~A}$ ) which was significantly different (lighter) from cytochrome oxidase (mitochondria; 1.16$1.18 \mathrm{~g} / \mathrm{cm}^{3}$; Fig. 4B), N-acetyl- $\beta$-glucosaminidase (lysosomes; $1 \cdot 18-1.20 \mathrm{~g} / \mathrm{cm}^{3}$; Fig. 4C), NADH- and NADPH-cytochrome $\mathrm{C}$ reductases (SER membranes, $1 \cdot 15-1 \cdot 17$ and $1 \cdot 16-1 \cdot 18 \mathrm{~g} / \mathrm{cm}^{3}$ respectively; Fig. 4E and F) (and peroxisomal and nuclear markers; data not shown) but overlapped with $5^{\prime}$-nucleotidase (plasma membranes; $1 \cdot 14-1 \cdot 17 \mathrm{~g} / \mathrm{cm}^{3}$; Fig. 4D). $\left[{ }^{3} \mathrm{H}\right]$ Progesterone binding equilibrated at a similar buoyant density in GC membranes from small, medium and large follicles (data not shown).

\section{Properties of GC membrane receptors}

Gradient fractions enriched in progesterone binding activity prepared from GC recovered from small, medium and large follicles were pooled for further study. $\left[{ }^{3} \mathrm{H}\right]$ Progesterone binding increased linearly with increasing GC membrane concentration (Fig. 5A). Specific binding was greatest to GC membranes from small compared with large follicles (Table $1 ; P<0 \cdot 02$ ), whilst GC from mediumsized follicles had intermediate levels of binding. Specific $\left[{ }^{3} \mathrm{H}\right]$ progesterone binding was not detected to membranes in the absence of digitonin (Fig. 5B, square symbol), but binding increased in a dose-dependent manner with increasing digitonin concentration (Fig. 5B).

Low levels of unlabelled progesterone competed for binding of the tracer in a dose-dependent manner (Fig. 5C; Table 2), whereas higher concentrations of testosterone and androstenedione were required to reduce binding by $50 \%$ (Table 2 ). Oestradiol, oestrone, pregnenolone, cortisol, cholesterol and the genomic progesterone receptor antagonist RU486 failed to inhibit binding even at micromolar concentrations (Fig. 5C). Scatchard plots (Fig. 5D) of progesterone binding to small GC membrane preparations revealed a single class of binding sites, with mean values of $K_{\mathrm{d}}$ and $\mathrm{B}_{\max }$ of $76 \times 10^{-9} \mathrm{~mol} / 1$ and $29 \mathrm{pmol} / \mathrm{mg}$ protein respectively. For comparison, values of $\mathrm{B}_{\max }$ and $K_{\mathrm{d}}$ for luteal membranes were $200 \times 10^{-9} \mathrm{~mol} / 1$ and $6.6 \mathrm{pmol} / \mathrm{mg}$ protein respectively (Rae et al. 1998).

\section{Thecal cells}

Sucrose gradient fractionation of bovine thecal homogenates demonstrated a density profile which was distinct from that of either bovine GC or mid-luteal tissues, but which resembled that often seen with late-luteal tissue. In three of five experiments, binding activity was associated with a broad, low-density thecal membrane fraction (Fig. 6A). The modal buoyant density of progesterone binding from a number of thecal preparations was $1 \cdot 10$ $1 \cdot 12 \mathrm{~g} / \mathrm{cm}^{3}$ (Fig. 6B). This differed from the density of the 


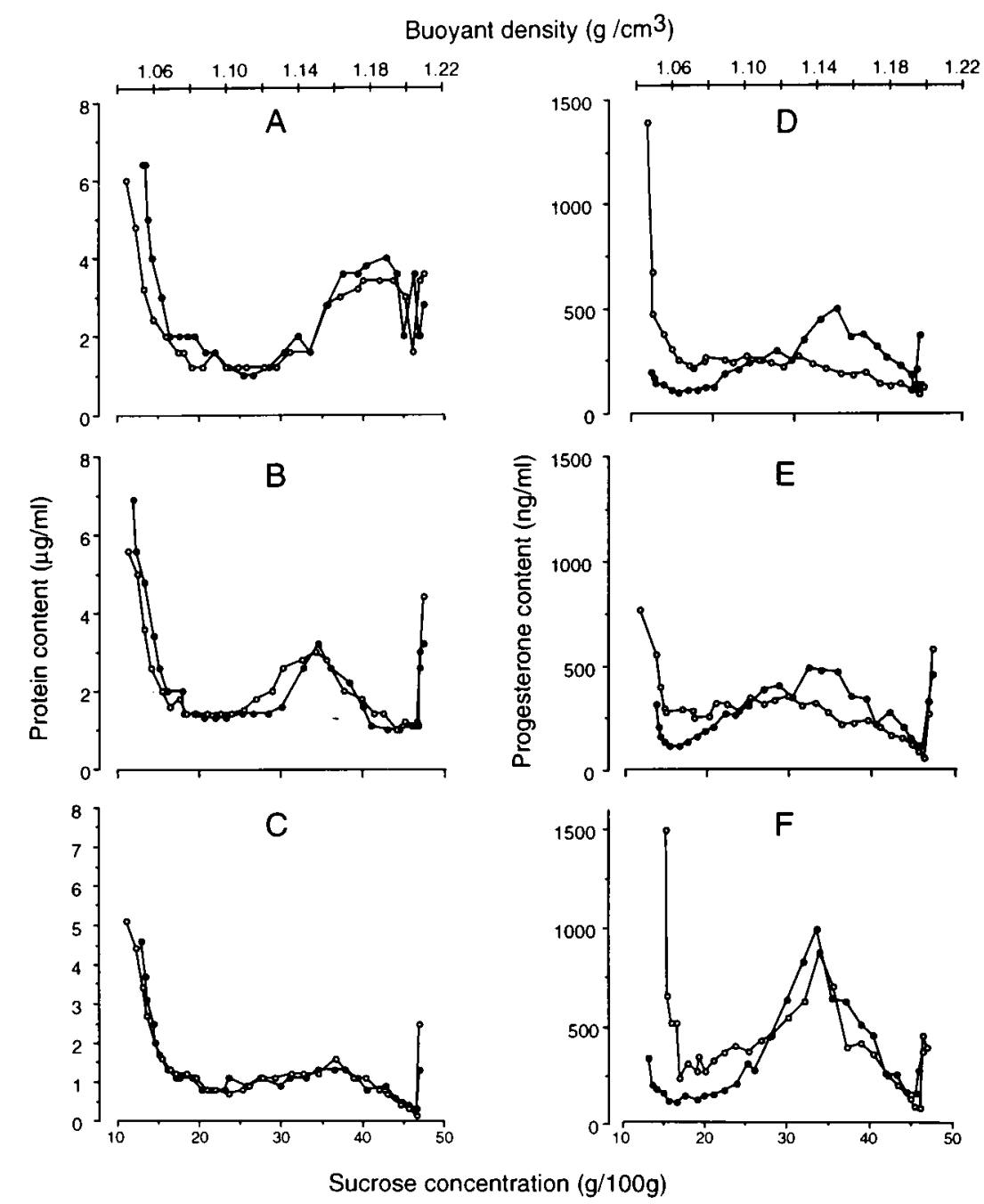

Figure 3 Protein $(\mathrm{A}-\mathrm{C})$ and progesterone content $(\mathrm{D}-\mathrm{F})$ of density gradient fractions from early- $(A$ and $D)$, mid- $(B$ and $E$ ) or late- $(C$ and $F$ ) luteal homogenates with $(\mathbf{O})$ or without (O) pretreatment with digitonin. Individual early-, mid- and late-luteal $\mathrm{CL}$ were homogenized in SET, preincubated with or without digitonin $\left(30 \mathrm{~min}, 0{ }^{\circ} \mathrm{C}\right)$ and aliquots fractionated on continuous sucrose density gradients. Fractions of each gradient were collected and aliquots assayed for protein $(\mathrm{A}-\mathrm{C})$ or progesterone content by RIA after hexane extraction (D-F). Content of each fraction was plotted against sucrose concentration. Similar data were obtained in a number of other less-complete experiments.

major organelles (cytochrome oxidase $\left(1 \cdot 15-1 \cdot 16 \mathrm{~g} / \mathrm{cm}^{3}\right.$; Fig. 6C), $\mathrm{N}$-acetyl- $\beta$-glucosaminidase $\left(1 \cdot 18-1 \cdot 20 \mathrm{~g} / \mathrm{cm}^{3}\right.$; Fig. 6D), nuclei and lysosomes (data not shown)), and from $5^{\prime}$-nucleotidase $\left(1 \cdot 13-1 \cdot 16 \mathrm{~g} / \mathrm{cm}^{3}\right.$; Fig. $\left.6 \mathrm{E}\right)$ and NADH-cytochrome C reductase $\left(1 \cdot 15-1 \cdot 17 \mathrm{~g} / \mathrm{cm}^{3}\right.$; Fig. 6F).

$\left[{ }^{3} \mathrm{H}\right]$ Progesterone binding to thecal membrane fractions increased linearly with increasing protein concentration (Fig. 7A) and levels did not differ significantly in thecal membranes from follicles at different stages of development (though only one preparation from small follicles was tested; Table 1). [ $\left.{ }^{3} \mathrm{H}\right]$ Progesterone binding to thecal membranes was also stimulated in a dose-dependent manner by digitonin (Fig. 7B). Thecal receptors had an affinity and specificity similar to those of GC receptors (Fig. 7C; Table 2), and Scatchard plots demonstrated a single class of binding sites (Fig. 7D) with values of $K_{\mathrm{d}}\left(67 \times 10^{-9}\right.$ $\mathrm{mol} / \mathrm{l})$ and $\mathrm{B}_{\max }(73 \mathrm{pmol} / \mathrm{mg}$ protein) similar to those of GC membrane binding sites. Values of $\mathrm{IC}_{50}$ for progesterone $(P<0 \cdot 05)$ and androgens (Table 2$)$ and the $K_{\mathrm{d}}$ for progesterone (cf. Rae et al. 1998) were higher for luteal compared with GC and thecal binding sites. 


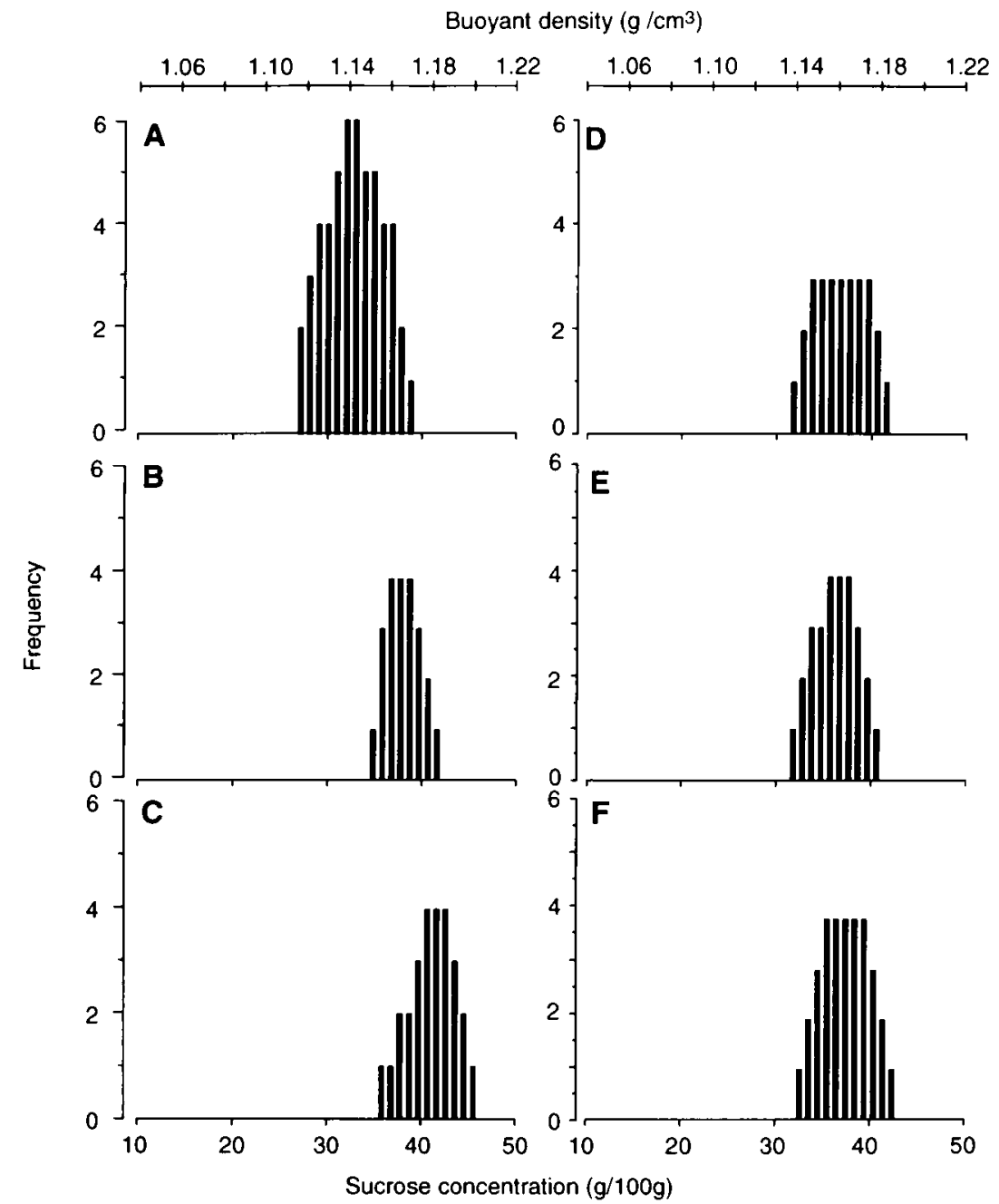

Figure 4 Buoyant density profiles of $\left[{ }^{3} \mathrm{H}\right]$ progesterone binding and marker enzymes of bovine GC. GC homogenates were prepared as described in Materials and Methods using cells aspirated from small $(<5 \mathrm{~mm}$ diameter) follicles. The whole of each homogenate was fractionated on continuous sucrose density gradients. Fractions of each gradient were collected and aliquots assayed (in triplicate) for $\left[{ }^{3} \mathrm{H}\right]$ progesterone binding in vitro $(\mathrm{A})$, and for cytochrome oxidase (B), $\mathrm{N}$-acetyl- $\beta$-glucosaminidase (C), 5'-nucleotidase (D), and $\mathrm{NADH}$ - and $\mathrm{NADPH}$-cytochrome $\mathrm{C}$ reductase activities ( $\mathrm{E}$ and $\mathrm{F}$ respectively). Frequency histograms of buoyant density were constructed. Similar data were obtained with homogenates of GC pooled from medium (5-10 mm diameter; $n=4)$ and large (>10 mm diameter; $n=3$ ) follicles (data not shown).

\section{Discussion}

Progesterone binding to early-, mid- and late-luteal

\section{CL membranes}

Previous studies demonstrated specific binding sites for exogenous $\left[{ }^{3} \mathrm{H}\right]$ progesterone in luteal membranes of a number of species (Bramley \& Menzies 1988a,b,c, 1993, Bramley et al. 1995, Rae et al. 1998). In the sheep CL, subcellular localization of progesterone binding sites was equivocal (Bramley \& Menzies 1998c), but in the horse CL
(Bramley et al. 1995) and mid-luteal bovine CL (Rae et al. 1998), specific receptors for progesterone were demonstrable in purified cell surface membranes. Steroid binding was not due to dissolution of the hydrophobic tracer in the lipid bilayer of the luteal cell, since binding of different steroids was unrelated to their partition coefficients in organic solvents, was destroyed by protease digestion, and could be solubilized by detergents with removal of most of the membrane lipid (Rae et al. 1998). Similarly, binding was not due to interaction of progesterone tracer with the 

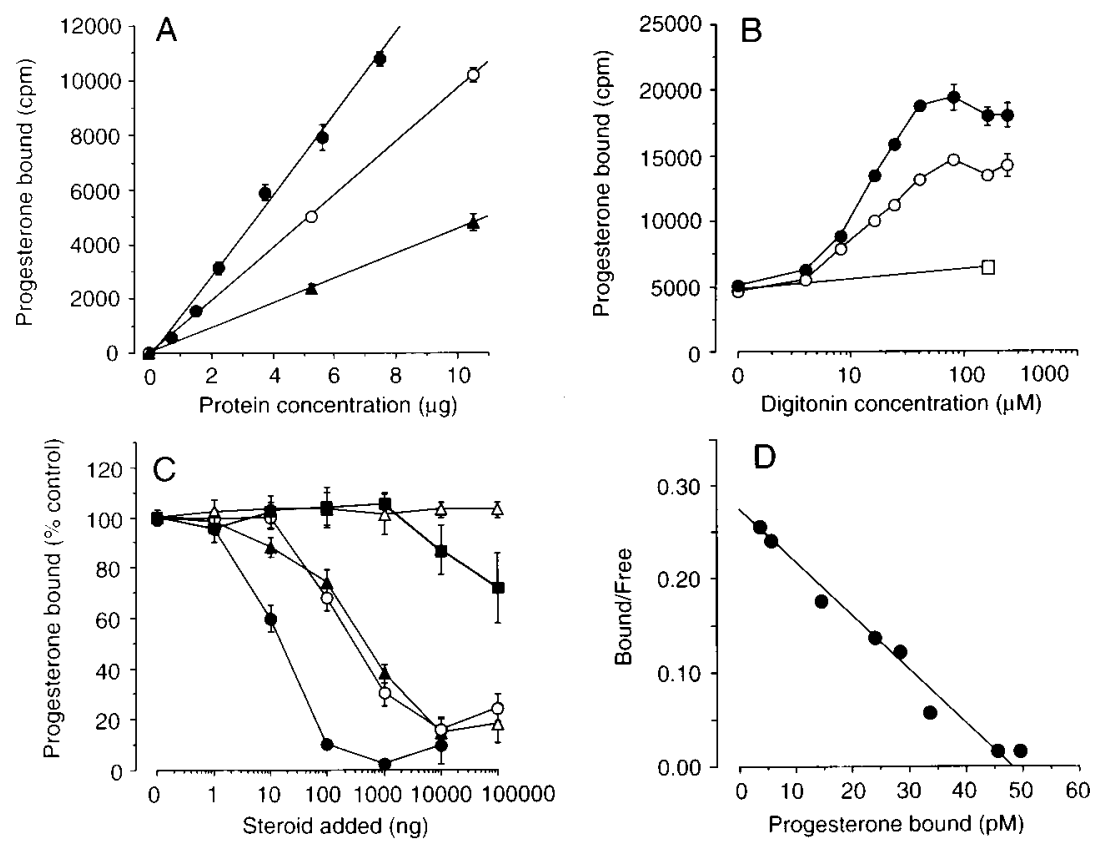

Figure 5 Properties of bovine GC membrane progesterone binding sites. Bovine GC sucrose density gradient fractions enriched in $\left[{ }^{3} \mathrm{H}\right]$ progesterone binding activity in vitro were pooled and assayed for protein content. (A) Triplicate aliquots of pooled GC membrane fractions from small $(\boldsymbol{O})$, medium $(\bigcirc)$ or large $(\boldsymbol{\Delta})$ follicles were incubated with $\left[{ }^{3} \mathrm{H}\right]$ progesterone in the presence of $250 \mu \mathrm{mol} / \mathrm{I}$ digitonin, and steroid bound specifically plotted against membrane protein added. (B) Triplicate aliquots of two different pools of small GC membrane fractions (circles) were incubated with $\left[{ }^{3} \mathrm{H}\right]$ progesterone in the absence or the presence of increasing concentrations of digitonin. $\square$ Binding with digitonin alone. (C) Triplicate aliquots of pooled GC membrane fractions were incubated with $\left[{ }^{3} \mathrm{H}\right]$ progesterone (50 000 c.p.m.) in the absence or presence of increasing concentrations of unlabelled progesterone $(\boldsymbol{\bullet})$, testosterone $(\boldsymbol{\Delta})$ or $\Delta^{4}$-androstenedione $(\bigcirc)$. Curves obtained with oestradiol, oestrone and pregnenolone ( $\boldsymbol{\square})$ and with cortisol, cholesterol, and RU486 $(\triangle)$ are shown by the same symbols for clarity. Data are means \pm S.E.M. of three separate experiments in triplicate. (D) Scatchard plot of $\left[{ }^{3} \mathrm{H}\right]$ progesterone binding to GC membranes.

steroid-binding sites of steroid dehydrogenases (SDHases), since inhibitors or substrates of a range of SDHases did not compete for progesterone binding in line with their affinity for the enzyme, metabolism of $\left[{ }^{3} \mathrm{H}\right]$ progesterone was not detected during binding incubation, and proges- terone binding could be resolved from $3 \beta-$ SDHase or $\mathrm{P}_{450}$ scc during purification (Rae et al. 1998).

Since luteal activity and progesterone secretion wax and wane markedly during the lifespan of the CL, we extended our earlier studies on mature CL to examine the

Table 1 Progesterone binding (pmol/mg protein) to purified membrane fractions from bovine GC and theca preparations isolated from follicles of different sizes. Membraneenriched sucrose density gradient fractions were prepared from GC and thecal tissues of follicles of different sizes, as described in Materials and Methods. Specific binding of $\left[{ }^{3} \mathrm{H}\right]$ progesterone was measured in triplicate at a range of membrane concentrations in the presence of digitonin, and binding adjusted from membrane protein content. Values are means \pm S.E.M. for $(n)$ pooled membrane fractions

Follicle size range (diameter)

\begin{tabular}{|c|c|c|c|}
\hline \multirow[b]{2}{*}{ Cell type } & Small $(<5 \mathrm{~mm})$ & Medium $(5-10 \mathrm{~mm})$ & Large $(>10 \mathrm{~mm})$ \\
\hline & & & \\
\hline GC & $6 \cdot 6 \pm 1 \cdot 2(6)$ & $4 \cdot 7 \pm 1 \cdot 3(4)$ & $2 \cdot 2 \pm 0 \cdot 2(3)^{*}$ \\
\hline Thecal cells & $3 \cdot 6(1)$ & $5 \cdot 9 \pm 2 \cdot 6(4)$ & $13 \cdot 2 \pm 2 \cdot 3(8)$ \\
\hline
\end{tabular}

${ }^{*} P<0 \cdot 02$, significantly different from membranes of small follicles. 
Table 2 Specificity and affinity of progesterone binding to isolated membrane fractions of bovine theca, GC and mid-luteal membranes. Membrane-enriched sucrose density gradient fractions were prepared from luteal, GC and thecal tissues, as described in Materials and Methods and Rae et al. (1998). Specific binding of $\left[{ }^{3} \mathrm{H}\right]$ progesterone was measured in triplicate at a range of membrane concentrations in the presence of digitonin, and binding adjusted for membrane protein content. Values are means \pm S.E.M. for $(n)$ separate determinations using three to six separate membrane preparations

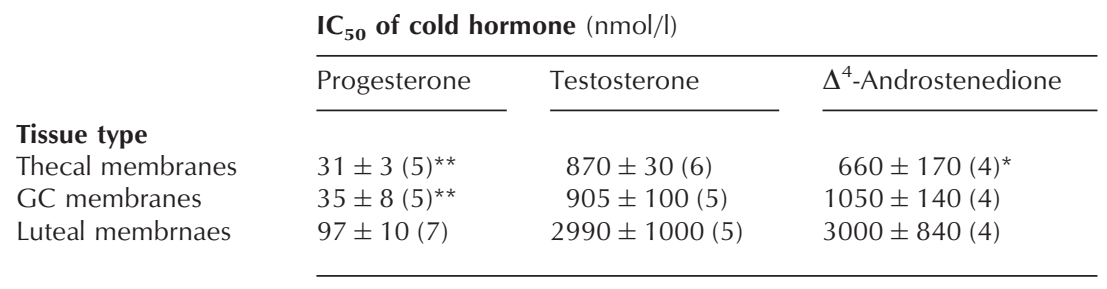

${ }^{*} P<0 \cdot 05,{ }^{* *} P<0 \cdot 01$, significantly different from luteal membranes.

presence and subcellular distribution of these binding sites in developing and regressing CL also. The buoyant density profiles for progesterone binding in vitro most closely resembled those of the luteal plasma membrane markers, overlapping with $5^{\prime}$-nucleotidase and luteinizing hormone (LH)-receptor (and the bovine luteal surface membrane marker, alkaline $5^{\prime}$-phosphodiesterase; data not shown) at all stages of the luteal phase, with and without digitonin perturbation, strongly suggesting a cell surface localization for steroid binding sites. However, minor density differences were noted between the distributions of $\left[{ }^{3} \mathrm{H}\right]$ progesterone binding and cell surface markers. Furthermore, the distributions of Golgi membrane and endosomal markers were not measured routinely in this study. Hence, assignment of progesterone binding sites to luteal cell surface membranes is not yet definitive.

Buoyant density profiles for all organelle markers at the three stages of the luteal phase were very similar, with some minor but interesting exceptions: (i) lower density of cytochrome oxidase in late-luteal CL, possibly reflecting changes in mitochondrial morphology and/or swelling associated with luteal regression; (ii) association of progesterone binding with lower density membrane vesicles in (some) late-luteal CL (Fig. 2D); and (iii) increased fragility of peroxisomal and lysosomal markers in late-luteal (regressing) CL (data not shown).

These changes (mitochondrial swelling, increased lysosomal fragility, membrane vesiculation) are all suggestive of cells undergoing apoptosis (a process known to be involved in luteolysis (Tilly 1996)), and may be a consequence of or a prelude to phagocytosis and autolysis of luteal cells undergoing structural luteal regression.

\section{Membrane progesterone receptors in bovine follicle cells}

Separation of 'large luteal' cells (generally believed to be derived from the GC of the preovulatory follicle) and 'small luteal' cells (thought to be derived from the thecal cells of the follicle (Koos \& Hansel 1981, Alila et al. 1988,
Behrman et al. 1993, Niswender \& Nett 1995, Hansel \& Blair 1996)) by elutriation suggested that membranes of large cells had higher progesterone binding levels than small cells (Rae et al. 1998). However, a number of factors prevented us from establishing unequivocally which luteal cell type(s) bound progesterone: (i) low but significant cross-contamination of luteal cell preparations; (ii) enzymatic or mechanical dissociation of the CL may have induced changes in the concentrations of cell surface progesterone receptors; and (iii) both 'luteal' cell fractions were contaminated by other cell types.

The bovine CL consists of a number of different cell types (endothelial cells, fibroblasts, macrophages), in addition to the characteristic steroidogenic cells (Wiltbank 1994, Fields \& Fields 1996). Endothelial cells account for more than half the cells in the bovine CL (O'Shea et al. 1989) and have been shown to express a non-genomic progesterone receptor (Falkenstein et al. 1996). Thus, much/all of the binding to luteal membranes could be accounted for by contamination with endothelial cell membranes. However, the demonstration of membrane binding sites in bovine GC (isolated from the avascular follicular fluid compartment of the follicle and therefore uncontaminated by endothelial cells) is strong evidence that endothelial cell contamination cannot account for progesterone binding, at least to GC membranes from healthy follicles.

Buoyant density profiles for $\left[{ }^{3} \mathrm{H}\right]$ progesterone binding most closely resembled those of the cell surface membrane markers, 5'-nucleotidase and LH-receptor in GC and (with alkaline phosphatase; data not shown) in thecal gradients (Figs 4 and 6), though progesterone binding often appeared to be associated with a somewhat less-dense membrane fraction. However, there was some overlap with SER markers, NAD $(\mathrm{P}) \mathrm{H}$-cytochrome $\mathrm{C}$ reductase(s) in these gradients, and assignment to either cell surface or SER membranes will require further experiments utilizing digitonin perturbation to differentiate cell membrane and intracellular membranes. 
Buoyant density $\left(\mathrm{g} / \mathrm{cm}^{3}\right)$
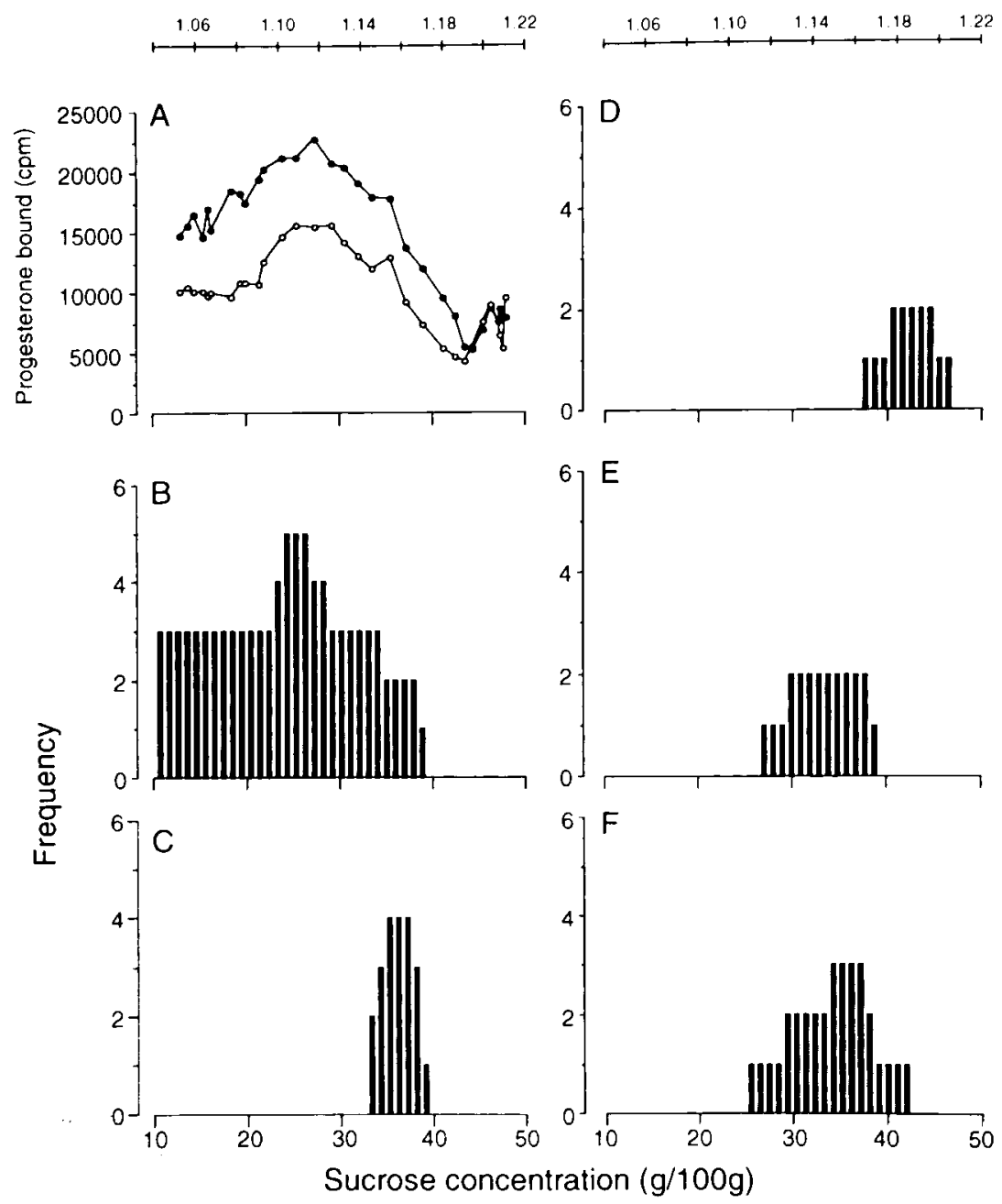

Figure 6 Buoyant density profiles of $\left[{ }^{3} \mathrm{H}\right]$ progesterone binding, and intracellular and cell surface membrane marker enzymes of bovine thecal tissue. Medium or large bovine follicles were hemisected after aspiration of follicular fluid and gentle scraping to remove attached mural GC and thecal tissue peeled from the inner follicle surface. Thecal tissue was homogenized and fractionated on sucrose density gradients, as described in the legend to Fig. 1. Aliquots of gradient fractions $(0,20 \mu \mathrm{l} ; \boldsymbol{0}, 50 \mu \mathrm{l})$ were assayed for $\left[{ }^{3} \mathrm{H}\right]$ progesterone binding in vitro in the presence of $250 \mu \mathrm{mol} / \mathrm{l}$ digitonin $(\mathrm{A})$, and binding activity plotted against sucrose concentration. Frequency histograms were constructed for $\left[{ }^{3} \mathrm{H}\right]$ progesterone binding in vitro (B), cytochrome oxidase $(\mathrm{C}), \mathrm{N}$-acetyl- $\beta$-glucosaminidase (D), 5'-nucleotidase (E) and NADH-cytochrome $\mathrm{C}$ reductase $(\mathrm{F})$.

Properties of follicular progesterone binding sites

Both GC and thecal membrane binding sites were specific for progesterone (Figs 5C and 7C), and the androgens, testosterone and $\Delta^{4}$-androstenedione, bound with much lower affinity (Table 2). Other steroids tested (oestradiol, oestrone, pregnenolone, cortisol, cholesterol, mifepristone) had very low potency in displacement assays. Scatchard plots of $\left[{ }^{3} \mathrm{H}\right]$ progesterone binding to GC and thecal membranes showed a single class of binding sites $\left(K_{\mathrm{d}}, 70 \times\right.$
$10^{-9} \mathrm{~mol} / \mathrm{l}$, Figs 5D and 7D). Interestingly, $\mathrm{IC}_{50}$ values of luteal binding sites for progesterone were significantly lower than for either thecal or GC membrane binding sites $(P<0 \cdot 05)$, suggesting a lower affinity, perhaps reflecting the effects of occupancy or down-regulation of the luteal receptor by the much higher concentrations of progesterone in the CL compared with the follicle (Table 2).

Specific binding increased in a linear manner with increasing concentrations of GC or thecal membrane fraction (Figs 5A and 7A). Levels of binding per $\mathrm{mg}$ 

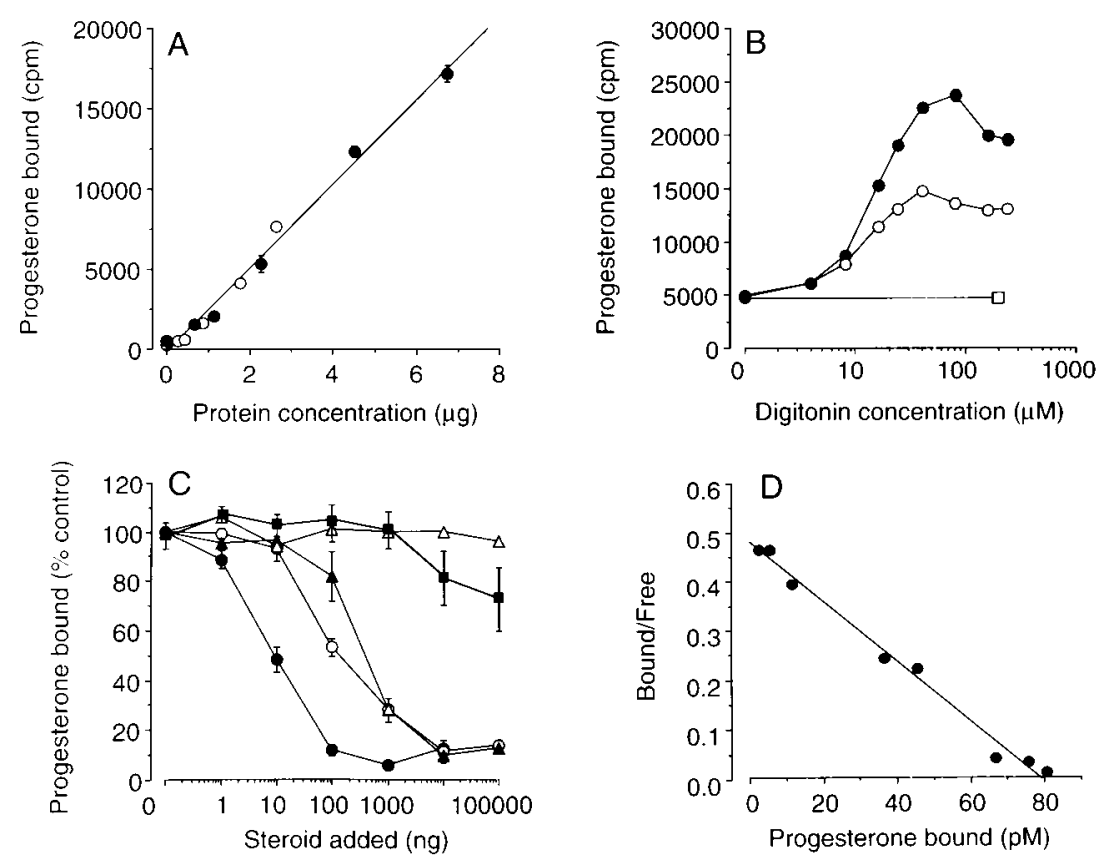

Figure 7 Properties of bovine thecal cell membrane progesterone binding sites. Fractions of bovine thecal cell gradients which were enriched in $\left[{ }^{3} \mathrm{H}\right]$ progesterone binding activity in vitro were pooled and assayed for protein content. (A) Triplicate aliquots of two separate pooled thecal membrane fractions were incubated with $\left[{ }^{3} \mathrm{H}\right]$ progesterone in the presence of $250 \mu \mathrm{mol} / \mathrm{l}$ digitonin, and steroid bound plotted against protein added. (B) Triplicate aliquots of two separate pooled thecal membrane fractions (15-25\% sucrose) were incubated with $\left[{ }^{3} \mathrm{H}\right]$ progesterone in the absence or the presence of increasing concentrations of digitonin. $\square$ Binding with digitonin only. (C) Triplicate aliquots of pooled thecal membrane fractions were incubated with $\left[{ }^{3} \mathrm{H}\right]$ progesterone in the absence or the presence of increasing concentrations of unlabelled progesterone $(\boldsymbol{O})$, testosterone $(\boldsymbol{\Delta})$ or $\Delta^{4}$-androstenedione $(\bigcirc)$. Curves obtained with oestradiol, oestrone and pregnenolone $(\boldsymbol{\square})$ and with cortisol, cholesterol, and RU486 $(\triangle)$ are shown by the same symbols for clarity. Data are means \pm S.E.M. of three separate experiments in triplicate. (D) Scatchard plot of $\left[{ }^{3} \mathrm{H}\right]$ progesterone binding to thecal membranes.

protein were not significantly different in thecal cell membranes from follicles of all size ranges (though only one thecal preparation from small follicles was analysed; Table 1). Thecal membranes (because of their lower buoyant density) were pooled from regions of the sucrose gradient (16-25\% sucrose) which were relatively uncontaminated by other organelles (see Fig. 3). Hence, the levels measured are probably an accurate reflection of thecal membrane binding site numbers.

Progesterone binding to GC membranes from large follicles was significantly lower than binding to GC membranes from small follicles (Fig. 5A; Table 1; $P<0 \cdot 02)$. A decrease in the number of binding sites per $\mathrm{GC}$ as the follicles mature suggests that non-genomic GC progesterone receptors may be developmentally regulated. However, GC fractions enriched in progesterone binding activity were pooled from regions of the gradient significantly more contaminated by other intracellular organelles than were thecal membranes. Thus, progesterone binding to pooled GC membrane fractions may be distorted somewhat by variable contamination with other organelles when expressed as binding per mg protein.

\section{Effects of digitonin on progesterone binding}

The observation that specific binding of radiolabelled progesterone to luteal (Rae et al. 1998), GC and thecal cell membranes required inclusion of digitonin in the binding incubation (Figs 5B and 7B) necessitates further comment, as this reflects on the physiological relevance of these receptors. Digitonin forms unimolecular complexes with steroids having a $\Delta^{5} 3 \beta$-hydroxy group and a C17 sidechain (Severs \& Robenek 1983). The serendipitous observation that digitonin (used to perturb the buoyant density of cell surface membranes) caused a decrease in cytosolic progesterone content, with a concomitant increase in progesterone bound to membranes (see Fig. 3D-F), suggested to us that it may affect progesterone binding to membranes directly. This led us to test its effects when added to the binding incubation, and to 
discover its powerful stimulatory effects on progesterone binding. These effects appear to be quite specific, as a range of saponins, detergents, cardenolides and cholesterol-complexing agents tested cannot mimic the effects of digitonin on progesterone binding (T A Bramley, M T Rae \& G S Menzies, unpublished observations).

The requirement for digitonin raises questions about the physiological importance of these binding sites. However, a recent report describes a very specific stimulation of progesterone binding to the physiologically important human sperm membrane progesterone receptor by digitonin (Ambhaikar \& Puri 1998). The process of capacitation of human sperm is associated with a depletion of sperm membrane cholesterol, and the action of progesterone on the induction of the acrosome reaction can be antagonized by repletion of sperm membrane cholesterol (Cross 1996, Cross \& Mahasrehti 1997, Lee et al. 1998). We suggest that digitonin may complex with unesterified membrane sterol(s), 'chemically depleting' membrane cholesterol and unmasking latent membrane progesterone receptors. Alternatively, digitonin may complex with an endogenous $\Delta^{5}$ $3 \beta$-hydroxy C17 steroid which is tightly bound to the receptor, so permitting access of the steroid tracer to the receptor (Rae et al. 1998). Further work to distinguish these two possibilities is currently in progress.

\section{Genomic and non-genomic progesterone receptors in the bovine ovary}

Genomic progesterone receptors are expressed in bovine ovarian tissue (Smith et al. 1995, Lioutas et al. 1997), and classically should be recovered in the cytosol and nuclear fractions following cell disruption and fractionation. However, although progesterone content of luteal cytosol and nuclear fractions was high at all stages of the luteal phase (Fig. 3D-F), binding of $\left[{ }^{3} \mathrm{H}\right]$ progesterone tracer to nuclear fractions in vitro was always low (and accountable for by contamination of nuclear pellets by unruptured cells), whilst (with the exception of some late-luteal and thecal preparations; Figs $2 \mathrm{D}$ and 6A) progesterone binding to cytosol fractions was generally much lower than to membranes. The failure to measure high steroid binding to luteal and GC cytosolic/nuclear fractions may reflect (i) the use of progesterone tracer rather than a metabolism-resistant progesterone analogue such as R5020, and (ii) the short duration and low temperature of incubation, which precludes exchange of tracer with endogenous bound steroid. Indeed, binding of R5020 tracer to bovine nuclear and cytosol fractions can be measured at $37^{\circ} \mathrm{C}$ ( $\mathrm{T}$ A Bramley \& G S Menzies, unpublished observations).

Interestingly, mifepristone (RU 38486), a classical antagonist of the genomic progesterone receptor, failed to compete for binding of radiolabelled progesterone to ovarian GC, thecal (or luteal) membranes even at high micromolar concentrations. Indeed, there is accumulating evidence that classical antagonists of other genomic steroid receptors fail to bind to non-genomic membrane receptors in the GC (Machelon et al. 1996) and in other tissues (Brann et al. 1996, Ramirez \& Zheng 1996, Rupprecht et al. 1996, Ambhaikar \& Puri 1998). Since mifepristone is a potent antigestagen in some species (humans, rats) but not others (chicken, hamster), one explanation for the failure of RU486 to block binding would be that it fails to bind to the bovine progesterone receptor. However, mifepristone is an effective antagonist of the upregulation of the oxytocin gene by progesterone in luteinizing bovine GC (Lioutas et al. 1997). Hence, mifepristone blockade may be a useful tool to dissect those effects of progesterone on bovine ovarian cells which are induced by genomic or non-genomic progesterone receptors (Curry \& Nothwick 1996).

Machelon et al. (1996) demonstrated rapid (within seconds), non-genomic actions of progesterone in porcine GC in vitro which were also triggered by progesterone covalently coupled to BSA, and which were not blocked by RU486. However, specific binding of progesterone to the porcine GC was not reported. Our present study shows for the first time the presence of specific progesterone binding sites in bovine thecal and GC membranes. In the light of the rapid effects of progesterone on calcium mobilization and inositol phosphate formation in the porcine GC, and the reported differences between the mechanisms of action of progesterone on calcium mobilization in nonluteinized and luteinized GC (Machelon et al. 1996), it will be of great interest to examine acute effects of progesterone on bovine luteal, GC and thecal cell functions in vitro. Moreover, isolation and cloning of a non-genomic progesterone receptor (Falkenstein et al. 1996, Meyer et al. 1996, 1998) offers the opportunity to study the expression and distribution of this receptor in ovarian tissues at different stages of the follicular and luteal phases of the cycle, and to compare the actions of progesterone on ovarian cell functions in species which express genomic progesterone receptors during the luteal phase (ruminant, primate) with those that express genomic progesterone receptors only transiently (rat).

\section{Acknowledgements}

We wish to thank Profs Mike Smith (University of Missouri), Bob Webb (University of Nottingham) and Alan McNeilly (MRC Reproductive Biology Unit, Edinburgh) for their helpful and constructive comments in the writing of this manuscript. Thanks also to Messrs Ted Pinner and Tom McFetters for the preparation of the figures. This work was sponsored in part by a grant from the UK Medical Research Council (T A B and M T R, G9532870). 


\section{References}

Aitken RJ, Harkiss D, Knox W, Paterson M \& Irvine S 1998 On the cellular mechanisms by which the bicarbonate ion mediates the extragenomic action of progesterone on human spermatozoa. Biology of Reproduction $\mathbf{5 8}$ 186-196.

Alexander NJ, Kim HK, Blye RR \& Blackmore PF 1996 Steroid specificity of the human sperm membrane progesterone receptor. Steroids 61 116-125.

Alila HW, Dowd JP, Corradino RA, Harris WV \& Hansel W 1988 Control of progesterone production in small and large bovine luteal cells separated by flow cytometry. Journal of Reproduction and Fertility 82 645-655.

Ambhaikar M \& Puri C 1998 Cell surface binding sites for progesterone on human spermatozoa. Molecular Human Reproduction 4 413-421.

Asem EK \& Conkright MD 1995 Role of progesterone in luteinizing hormone-induced fibronectin production and deposition by chicken granulosa cells in vitro. Comparative Biochemistry and Physiology 112C 247-255.

Bandyopadhyay A, Bandyopadhyay J, Choi H-H, Choi H-S \& Kwon H-B 1998 Plasma membrane mediated action of progesterone in amphibian (Rana dybowskii) oocyte maturation. General and Comparative Endocrinology 109 293-301.

Baulieu E-E \& Robel P 1995 Nongenomic mechanisms of action of steroid hormones. Ciba Foundation Symposium 191 24-42.

Behrman HR, Endo T, Aten RF \& Musicki B 1993 Corpus luteum function and regression. Reproductive Medicine Review 2 153-180.

Bielefeldt K, Waite L, Abboud FM \& Conklin JL 1996 Nongenomic effects of progesterone on human intestinal smooth muscle cells. American Journal of Physiology - Gastrointestinal and Liver Physiology 34 G370-G376.

Blackmore PF, Beebe SJ, Danforth DR \& Alexander N 1990 Progesterone and 17a-hydroxyprogesterone novel stimulators of calcium influx in human sperm. Journal of Biological Chemistry 265 1376-1380.

Blackmore PF, Im WB \& Bleasdale JE 1994 The cell surface receptor which stimulates calcium influx in human sperm is unlike the $A$ ring reduced steroid site on the $\mathrm{GABA}_{\mathrm{A}}$ receptor/chloride channel. Molecular and Cellular Endocrinology 104 237-243.

Blackmore PF, Fisher JF, Spilman CH \& Bleasdale JE 1996 Unusual steroid specificity of the cell surface progesterone receptor on human sperm. Molecular Pharmacology 49 727-739.

Bramley TA \& Menzies GS 1988a Subcellular fractionation of the porcine corpus luteum sequestration of progesterone in a unique particulate fraction. Journal of Endocrinology 117 341-354.

Bramley TA \& Menzies GS $1988 b$ Association of progesterone with a unique particulate fraction of the human corpus luteum. Journal of Endocrinology 116 307-312.

Bramley TA \& Menzies GS 1988c Subcellular fractionation of the ovine corpus luteum association of progesterone with ovine luteal membranes. Molecular and Cellular Endocrinology 59 135-146.

Bramley TA \& Menzies GS 1993 Specificity studies of particulate binding sites for steroid hormones in subcellular fractions of the porcine corpus luteum. Journal of Endocrinology 136 371-380.

Bramley TA, Menzies GS \& Watson ED 1995 Particulate progesterone binding sites in the equine corpus luteum. Biology of Reproduction Monograph, Equine Reproduction VI 323-328.

Brann DW, Hendry LB \& Mahesh VB 1996 Emerging diversities in the mechanism of action of steroid hormones. Journal of Steroid Biochemistry and Molecular Biology 52 113-133.

Caldwell JD, Walker CH, Faggin BM, Carr RB, Pedersen CA \& Mason GA 1995 Characterization of progesterone-3-[125 I-BSA] binding sites in the medial preoptic area and anterior hypothalamus. Brain Research 693 225-232.

Cross NL 1996 Human seminal plasma prevents sperm from becoming acrosomally responsive to the agonist progesterone: cholesterol is the major inhibitor. Biology of Reproduction 54 138-145.
Cross NL \& Mahasrehti P 1997 Prostasome fraction of human seminal plasma prevents sperm from becoming acrosomally responsive to the agonist progesterone. Archives of Andrology 39 39-44.

Curry TE Jr \& Nothwick WB 1996 Mifepristone and ovarian function. Clinical Obstetrics and Gynecology 39 486-497.

Dar DE \& Zinder O 1997 Short term effects of steroids on catecholamine secretion from bovine adrenal medulla chromaffin cells. Neuropharmacology 36 1783-1788.

Duffy DM, Molskness TA \& Stouffer RL 1996 Progesterone receptor messenger ribonucleic acid and protein in luteinized granulosa cells of Rhesus monkeys are regulated in vitro by gonadotropins and steroids. Biology of Reproduction 54 888-895.

Eisen C, Meyer C \& Wehling M 1997 Characterization of progesterone membrane binding sites from porcine liver probed with a novel azido-progesterone ligand. Cellular and Molecular Biology 43 165-173.

Falkenstein E, Meyer C, Eisen C, Scriba PC \& Wehling M 1996 Full-length cDNA sequence of a progesterone membrane-binding protein from porcine vascular smooth muscle cells. Biochemical and Biophysical Research Communications 229 86-89.

Fields MJ \& Fields PA 1996 Morphological characteristics of the bovine corpus luteum during the estrous cycle and pregnancy. Theriogenology 45 1295-1325.

Hansel W \& Blair RM 1996 Bovine corpus luteum: a historic overview and implications for future research. Theriogenology 45 1267-1294.

Jacob A, Hurley I, Mandel FS, Herschlag A, Cooper GW \& Benoff S 1998 Human sperm non-nuclear progesterone receptor expression is a novel marker for fertilization outcome. Molecular Human Reproduction 4 533-542.

Joels M 1997 Steroid hormones and excitability in the mammalian brain. Frontiers in Neuroendocrinology 18 2-48.

Jones LS, Ottobre JS \& Pate JL 1992 Progesterone regulation of luteinizing hormone receptors on cultured bovine luteal cells. Molecular and Cellular Endocrinology 85 33-39.

Koos RD \& Hansel W 1981 The large and small cells of the bovine corpus luteum: ultrastructural and functional differences. In Dynamics of Ovarian Function, pp 197-203. Eds NB Schwartz \& M Hunzicker-Dunn. New York: Raven Press.

Lee GC-Y, Khorasani AM \& Dorjee S 1998 Assessment of progesterone-induced acrosome reaction by biotinylated monoclonal antibody probes. American Journal of Reproductive Immunology 39 164-171.

Lioutas C, Einspanier A, Kascheike B, Walter N \& Ivell R 1997 An autocrine progesterone positive feedback loop mediates oxytocin upregulation in bovine granulosa cells during luteinization. Endocrinology 138 5059-5062.

Liu Z \& Patino R 1993 High-affinity binding of progesterone to the plasma membrane of Xenopus oocytes: characteristics of binding and hormonal and developmental control. Biology of Reproduction 49 980-988.

Lowry OH, Rosebrough NJ, Farr AL \& Randall RJ 1951 Protein measurement with the Folin phenol reagent. Journal of Biological Chemistry 193 265-275.

Luconi M, Bonaccorsi L, Maggi M, Pecchioli P, Krausz C, Forti G \& Baldi E 1998 Identification and characterization of functional nongenomic progesterone receptors on human sperm membrane. Journal of Clinical Endocrinology and Metabolism 83 877-885.

Machelon V, Nome F, Grosse B \& Lieberherr M 1996 Progesterone triggers rapid transmembrane calcium influx and/or calcium mobilization from the endoplasmic reticulum, via a Pertussisinsensitive G-protein in granulosa cells in relation to luteinization process. Journal of Cellular Biochemistry 61 619-628.

Mahesh VB, Brann DW \& Hendry LB 1996 Diverse modes of action of progesterone and its metabolites. Journal of Steroid Biochemistry and Molecular Biology 56 209-219. 
Metherall JE, Waugh K \& Li H 1996 Progesterone inhibits cholesterol biosynthesis in cultured cells accumulation of cholesterol precursors. Journal of Biological Chemistry $2712627-2633$.

Meyer C, Schmid R, Scriba PC \& Wehling M 1996 Purification and partial sequencing of high-affinity progesterone-binding site(s) from porcine liver membranes. European Journal of Biochemistry 239 726-731.

Meyer C, Schmid R, Schmieding K, Falkenstein E \& Wehling M 1998 Characterization of high affinity progesterone-binding membrane proteins by an antipeptide antiserum. Steroids $\mathbf{6 3}$ 111-116.

Niswender GD \& Nett TM 1995 Corpus luteum and its control in infraprimate species. In The Physiology of Reproduction, edn 2, pp 781-816. Eds E Knobil \& JD Neill. New York: Raven Press.

O’Shea JD, Rodgers RJ \& D'Occhio MJ 1989 Cellular composition of the cyclic corpus luteum of the cow. Journal of Reproduction and Fertility 85 483-487.

Parinaud J \& Milhet P 1996 Progesterone induces $\mathrm{Ca}^{++}$-dependent $3^{\prime}, 5^{\prime}$-cyclic adenosine monophosphate increase in human sperm. Journal of Clinical Endocrinology and Metabolism 81 1357-1360.

Park-Sarge O, Parmer TG \& Gibori G 1996 Does the rat corpus luteum express the progesterone receptor gene? Endocrinology 136 1537-1543.

Picard D 1998 Steroids tickle cells inside and out. Nature 392 437-438.

Pinter JH, Deep C \& Park-Sarge O-K 1996 Progesterone receptors expression and regulation in the mammalian ovary. Clinical Obstetrics and Gynecology 39 424-435.

Rae MT, Menzies GS, McNeilly AS, Woad K, Webb R \& Bramley TA 1998 Specific non-genomic, membrane-localised binding sites for progesterone in the bovine corpus luteum. Biology of Reproduction 58 1394-1406.

Ramirez VD \& Zheng J 1996 Membrane sex-steroid receptors in the brain. Frontiers in Neuroendocrinology 17 402-439.

Revelli A, Massobrio M \& Tesarik J 1998 Nongenomic actions of steroid hormones in reproductive tissues. Endocrine Reviews 19 3-17.

Rossmanith WG, Schick MS, Benz R \& Lauritzen C 1991 Autonomous progesterone secretion from the bovine corpus luteum in vitro. Acta Endocrinologica 124 179-187.
Rupprecht R, Hauser CA, Trapp T \& Holsboer F 1996 Neurosteroids molecular mechanisms of action and psychopharmacological significance. Journal of Steroid Biochemistry and Molecular Biology 56 163-168.

Sabeur K, Edwards DP \& Meizel S 1996 Human sperm plasma membrane receptor(s) and the acrosome reaction. Biology of Reproduction 54 993-1001.

Sadler SE \& Maller JL 1982 Identification of a steroid receptor on the surface of Xenopus oocytes by photoaffinity labelling. Journal of Biological Chemistry 257 355-361.

Severs NJ \& Robenek H 1983 Detection of microdomains in biomembranes; an appraisal of recent developments in freeze-fracture cytochemistry. Biochimica et Biophysica Acta 737 373-408.

Smith GW, Gentry PC, Long DK, Bao B, Roberts RM \& Smith MF 1995 Expression of progesterone-receptor (P4R) messenger RNA within ovine post-surge follicles and corpora lutea. Biology of Reproduction $\mathbf{5 2} 151$

Stone AB 1974 A simplified method for preparing sucrose gradients. Biochemical Journal 137 117-120.

Tesarik J, Moos J \& Mendoza C 1993 Stimulation of protein tyrosine phosphorylation by a progesterone receptor on the cell surface of human sperm. Endocrinology 133 328-335.

Tilly JL 1996 Apoptosis and ovarian function. Reviews in Reproduction 1 162-172.

Wehling M 1997 Specific, nongenomic actions of steroid hormones. Annual Review of Physiology 59 365-393.

Weibe JP 1997 Nongenomic actions of steroids on gonadotropin release. Recent Progress in Hormone Research 52 71-101.

Wiltbank MC 1994 Cell types and hormonal mechanisms associated with mid-cycle corpus luteum function. Journal of Animal Science 72 1873-1883.

Zheng J, Ali A \& Ramirez VD 1996 Steroids conjugated to bovine serum albumin as tools to demonstrate specific steroid neuronal membrane binding sites. Psychiatry and Neuroscience 21 187-197.

Received 23 April 1998

Revised manuscript received 7 July 1998

Accepted 27 July 1998 